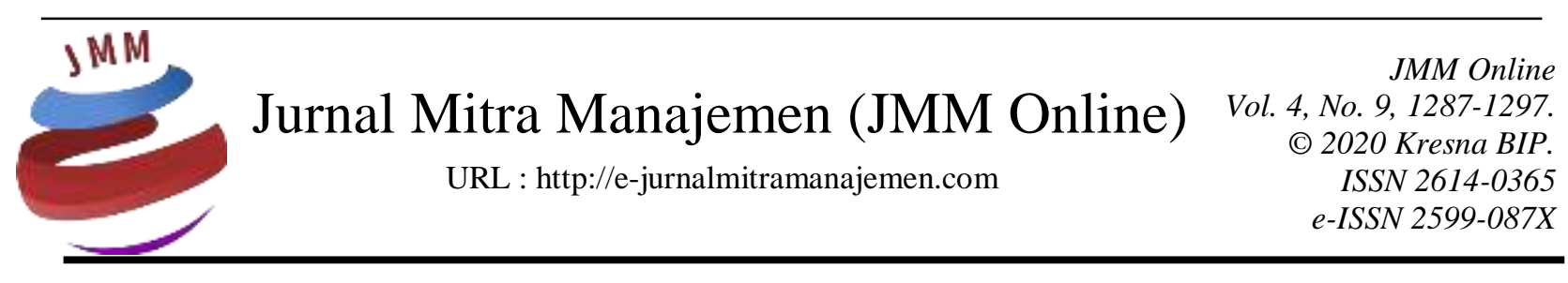

\title{
PENGARUH EKUITAS MEREK TERHADAP KEPUTUSAN PEMBELIAN SMARTPHONE SAMSUNG DI KOTA BANDUNG
}

\author{
Annisa Yasya Zhafira ${ }^{1)}$, Indira Rachmawati ${ }^{2)}$ \\ Universitas Telkom
}

INFORMASI ARTIKEL

Dikirim : 31 Agustus 2020

Revisi pertama : 07 September 2020

Diterima : 14 September 2020

Tersedia online : 01 Oktober 2020

Kata Kunci: Ekuitas Merek, Keputusan Pembelian, Smartphone Samsung

Email : annisayasya@gmail.com ${ }^{1)}$, indira.rach@gmail.com ${ }^{2)}$

\section{ABSTRAK}

Ekuitas merek adalah seperangkat aset dan kewajiban merek yang terkait yang dapat menambah atau mengurangi nilai yang diberikan oleh sebuah produk atau jasa bagi perusahaan dan pelanggan. Ekuitas merek akan membantu pelanggan dalam mengartikan proses informasi terkait produk dan dapat mempengaruhi kepercayaan konsumen saat dalam pengambilan keputusan. Dengan adanya ekuitas merek dalam suatu produk, produk tersebut akan memiliki keunggulan kompetitif dalam perusahaan dan membuat konsumen dapat membuat keputusan pembelian setelah mengenal secara keseluruhan merek.

Tujuan dari penelitian ini adalah untuk menganalisis pengaruh elemen-elemen ekuitas merek tersebut terhadap keputusan pembelian konsumen pada pengguna smartphone Samsung yang berada di Kota Bandung. Penelitian ini termasuk ke dalam penelitian kuantitatif. Teknik analisis data yang digunakan dalam penelitian ini adalah dengan menggunakan uji regresi berganda. Data yang digunakan dalam penelitian ini adalah data primer yang berasal dari responden yang telah mengisi kuesioner sebanyak 400 orang pengguna smartphone Samsung dengan menggunakan metode populasi nonprobability sampling. 


\section{PENDAHULUAN \\ Latar Belakang}

Dewasa ini, merek menjadi peran penting dalam meningkatkan hidup konsumen dan menjadi nilai keuangan perusahaan. Dalam sebuah bisnis, merek dapat menunjukkan satu tingkat mutu tertentu, sehingga konsumen yang puas dapat memilih produk lebih mudah. Pemasar perlu membangun ekuitas merek dengan menciptakan struktur pengetahuan merek yang tepat kepada konsumen yang tepat.

Dibandingkan dengan aset perusahaan yang lain, merek dianggap memberikan jaminan dalam keberlangsungan suatu usaha. Jika perusahaan dapat melakukan branding yang tepat sehingga mampu meningkatkan ekuitas merek, maka merek tersebut dapat mendongkrak kinerja perusahaan dan mampu membawa perusahaan di tengah persaingan yang semakin tajam. Maka dari itu, banyak perusahaan yang beranggapan bahwa kunci keberhasilan usaha adalah merek. Merek membuat konsumen konsumen dapat membedakan kualitas dari suatu produk, sehingga konsumen dapat menentukan yang terbaik bagi konsumen tersebut.

Fenomena persaingan antara perusahaan mendorong setiap perusahaan menyadari akan suatu kebutuhan untuk memaksimalkan aset-aset perusahaan demi kelangsungan hidup perusahaan, khususnya untuk perusahaan yang menghasilkan produk smartphone. Saat ini persaingan perusahaan untuk memperebutkan konsumen tidak lagi terbatas pada atribut fungsional produk saja misalnya seperti kegunaan produk, melainkan sudah dikaitkan dengan merek yang mampu memberikan citra khusus bagi penggunanya.

Kondisi persaingan saat ini yang terjadi pada produk smartphone. Adanya banyak merek smartphone yang baru pada saat ini, mendorong konsumen untuk melakukan identifikasi dalam pengambilan keputusan saat menentukan suatu merek yang menurut mereka memenuhi kriteria barang yang mereka butuhkan. Proses identifikasi akan membuat merek menjadi suatu alat pembeda dan dapat juga menjadi kriteria utama dalam proses pengambilan keputusan pembelian konsumen. Konsumen yang melakukan pembelian smartphone pada saat ini mengalami perkembangan yang pesat dan juga beberapa perubahan, yaitu konsmuen kini lebih banyak ditawarkan berbagai macam produk smartphone. Kondisi ini juga terjadi di Kota Bandung, dimana perilaku konsumen ingin mendapatkan produk yang praktis. 


\section{Gambar 1. Pangsa Pasar Samsung (Global) Samsung Bertahan Jadi Pemimpin Pasar Smartphone Dunia}

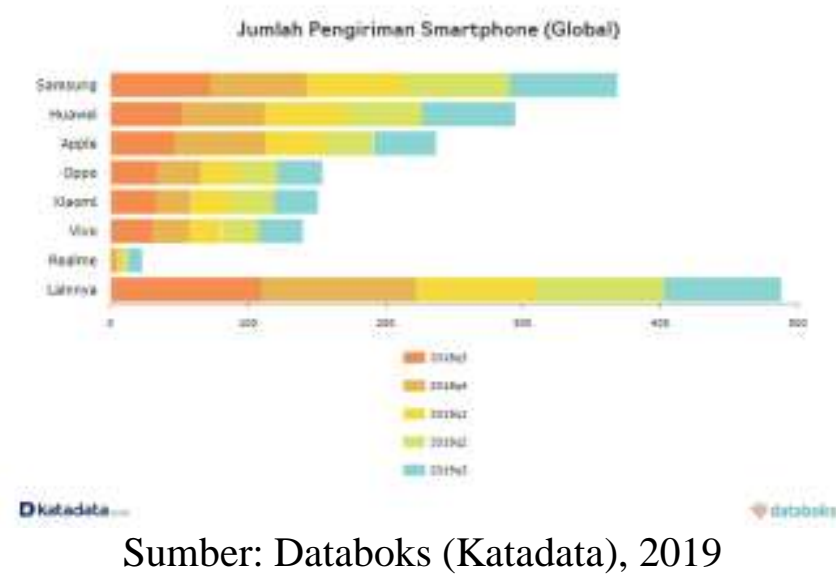

Samsung masih bertahan sebagai pemimpin pasar ponsel pintar (smartphone) global. Data Counterpoint Research mencatat sejak kuartal III-2018 hingga tepat setahun setelahnya, posisi Samsung belum bergeser. Samsung masih memegang $21 \%$ pasar smartphone dunia. Pada kuartal III-2018, smartphone asal Korea Selatan itu berhasil mengirimkan 72,3 juta unit ponsel ke seluruh dunia. Meski sempat menurun pada kuartal IV 2018, jumlahnya kembali meningkat hingga kuartal III-2019 sebesar 78,2 juta unit ponsel. Pertumbuhan Samsung mencapai 8,4\% dari tahun ke tahun, bukti merek tersebut menguasai seperlima pasar smartphone global. Hal ini didukung kuatnya penjualan Note 10 dan seri Galaxy A. (Databoks, 2019)

Ekuitas merek merupakan pendorong untuk meningkatkan penjualan sehingga tujuan PT Samsung dapat tercapai. Pengetahuan mengenai ekuitas merek menjadi penting bagi PT Samsung pada saat dihadapkan dengan beberapa permasalahan seperti menurunnya pendapatan perusahaan yang disebabkan oleh menurunnya daya beli konsumen terhadap suatu jasa sehingga mengakibatkan melambatnya pertumbuhan dan perkembangan perusahaan.

Dari gambaran di atas, maka peneliti tertarik untuk meneliti lebih dalam mengenai "Pengaruh Ekuitas Merek Terhadap Keputusan Pembelian Smartphone Samsung di Kota Bandung" dengan harapan penelitian ini dapat dijadikan referensi oleh perusahaan Samsung dalam meningkatkan maupun mempertahankan perusahaannya.

\section{Rumusan Masalah}

Berdasarkan latar belakang diatas, maka rumusan masalah dalam penelitian ini adalah sebagai berikut.

1. Bagaimana tanggapan pengguna smartphone Samsung di Kota Bandung terhadap brand awareness smartphone Samsung?

2. Bagaimana tangapan pengguna smartphone Samsung di Kota Bandung terhadap brand association smartphone Samsung? 
3. Bagaimana tanggapan pengguna smartphone Samsung di Kota Bandung terhadap brand perceived quality Samsung?

4. Bagaimana tanggapan pengguna smartphone Samsung di Kota Bandung terhadap brand loyalty smartphone Samsung?

5. Seberapa besar pengaruh brand awareness terhadap keputusan pembelian smartphone Samsung di Kota Bandung?

6. Seberapa besar pengaruh pengaruh brand association terhadap keputusan pembelian Smartphone Samsung di Kota Bandung?

7. Seberapa besar pengaruh pengaruh perceived quality terhadap keputusan pembelian Smartphone Samsung di Kota Bandung?

8. Seberapa besar pengaruh brand loyalty terhadap keputusan pembelian Smartphone Samsung di Kota Bandung?

9. Seberapa besar pengaruh brand awareness, brand assocation, perceived quality, dan brand loyalty terhadap keputusan pembelian Smartphone Samsung di Kota Bandung?

\section{Tujuan Penelitian}

Berdasarkan rumusan masalah diatas, maka tujuan dalam penelitian ini adalah sebagai berikut.

1. Mengetahui tanggapan pengguna smartphone Samsung di Kota Bandung terhadap brand awareness smartpone Samsung.

2. Mengetahui tanggapan pengguna smartphone Samsung di Kota Bandung terhadap brand assosication smartpone Samsung.

3. Mengetahui tanggapan pengguna smartphone Samsung di Kota Bandung terhadap perceived quality smartpone Samsung.

4. Mengetahui tanggapan pengguna smartphone Samsung di Kota Bandung terhadap brand loyalty smartpone Samsung.

5. Mengetahui dan menjelaskan pengaruh antara brand awareness terhadap keputusan pembelian pada smartphone Samsung di kota Bandung.

6. Mengetahui dan menjelaskan pengaruh antara brand association terhadap keputusan pembelianpada smartphone Samsung di kota Bandung.

7. Mengetahui dan menjelaskan pengaruh antara perceived quality terhadap keputusan pembelianpada smartphone Samsung di kota Bandung.

8. Mengetahui dan menjelaskan pengaruh antara brand loyalty terhadap keputusan pembelianpada smartphone Samsung di kota Bandung.

9. Mengetahui dan menjelaskan pengaruh antara brand awareness, brand assocation, perceived quality, dan brand loyalty terhadap keputusan pembelian pada smartphone Samsung di kota Bandung.

\section{KAJIAN PUSTAKA}

\section{Ekuitas Merek}

Menurut Kotler dan Keller (2009:263), ekuitas merek sebagai nilai tambah yang diberikan pada produk dan jasa. Ekuitas merek dapat tercermin dalam cara konsumen berfikir, merasa, dan bertindak dalam hubungannya dengan merek, dan juga harga, pangsa pasar, dan profitabilitas yang diberikan merek bagi perusahaan. 
Berdasarkan pendapat yang dikemukakan oleh para ahli di atas, maka ekuitas merek dapat disimpulkan sebagai seperangkat nilai sebuah produk yang dapat dilihat berdasarkan persepsi atau pandangan konsumen terhadap produk tersebut. Semakin bagus ekuitas merek pada sebuah produk, maka menandakan bahwa merek tersebut juga dekat dengan pelanggan.

\section{Brand Awareness}

Menurut Shimp (2003:11) brand awareness adalah kemampuan sebuah merek untuk muncul dalam benak konsumen ketika mereka sedang memikirkan kategori produk tertentu dan seberapa mudahnya nama tersebut dimunculkan. Berdasarkan definisi tersebut, maka dapat disimpulkan bahwa brand awareness adalah seberapa jauh sebuah produk dapat mempengaruhi persepsi konsumen dalam mengenal atau mengingat produk tersebut.

\section{Brand Association}

Menurut Aaker (1997) dalam Simamora (2001) Asosiasi merek adalah segala hal yang berkaitan tentang merek dalam ingatan. Asosiasi tidak hanya eksis, namun juga mempunyai tingkat kekuatan. Berdasarkan definisi tersebut, maka dapat ditarik kesimpulan bahwa brand association adalah sekumpulan nilai produk yang dipengaruhi oleh konsumen. Sebuah merek akan dipersepsikan secara berbeda-beda oleh konsumen dalam bentuk yang akan mengantarkan konsumen pada kesimpulannya atas merek tersebut.

\section{Perceived Quality}

Definisi perceived quality adalah persepsi konsumen terhadap kualitas atau keunggulan suatu produk atau layanan yang ditinjau dari fungsinya secara relatif dengan produk-produk lain, Aaker (1997) dalam Simamora (2001). Berdasarkan pemaparan mengenai perceived quality, maka dapat disimpulkan bahwa perceived quality adalah tanggapan konsumen terhadap mutu sebuah produk, biasanya tanggapan tergantung seberapa lama konsumen telah menggunakan produk tersebut.

\section{Brand Loyalty}

Menurut Aarker dalam Nagar (2009) berpendapat bahwa loyalitas merek menujukan pola pembelian yang konsisten terhadap merek tertentu sepanjang waktu dan juga sikap menyenangkan terhadap sebuah merek. Berdasarkan pemaparan tersebut, maka dapat disimpulakn bahwa brand loyalty merupakan kesetiaan konsumen dalam menggunakan sebuah produk dan tidak beralih ke merek lain.

\section{Keputusan Pembelian}

Menurut Tjiptono (2012) keputusan pembelian adalah sebuah proses dimana konsumen mengenal masalahnya, mencari informasi mengenai produk atau merek tertentu dan mengevaluasi secara baik masing-masing alternatif tersebut dapat memecahkan masalahnya, yang kemudian mengarah kepada keputusan pembelian. Berdasarkan definisi di atas, maka dapat ditarik kesimpulan bahwa keputusan 
pembelian adalah sebuah proses konsumen untuk menentukan pembelian akhir atas suatu produk yang ia butuhkan.

\section{Kerangka Pemikiran}

Dalam penelitian ini, penulis memberikan subvariabel terhadap ekuitas merek yang terdiri dari kesadaran merek, asosiasi merek, persepsi merek, dan loyalitas merek dalam menganalisis pengaruhnya terhadap keputusan pembelian pada produk Smartphone Samsung di Kota Bandung.

\section{Gambar 2. Kerangka Pemikiran}

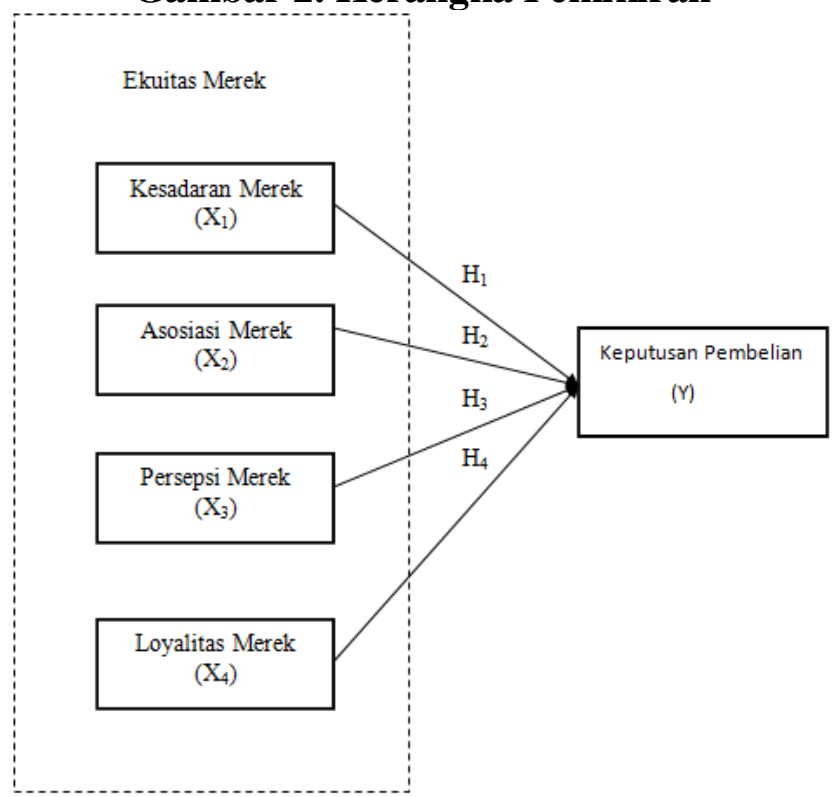

Sumber: Olahan Penulis acuan dari Sudarsono dan Kurniawati (2013)

\section{METODE PENELITIAN}

\section{Jenis Penelitian}

Penelitian ini menggunakan metode kuantitatif dan berdasarkan tujuannya termasuk ke dalam jenis penelitian deskriptif yaitu untuk mengetahui tanggapan konsumen mengenai ekuitas merek smartphone Samsung.

\section{Objek dan Waktu Penelitian}

Penelitian ini memiliki tujuan untuk mengetahui pengaruh ekuitas merek terhadap keputusan pembelian smartphone Samsung di Kota Bandung. Batasan penelitian ini dibatasi pada objek penelitian pengguna smartphone Samsung di Kota Bandung. Waktu dan periode penelitian ini dimulai dari Maret 2020 - Juli 2020.

\section{Teknik Pengumpulan Data}

Penelitian ini menggunakan teknik non-probability sampling dengan menggunakan rumus Bernoulli sehingga diperoleh sampel sebanyak 385 orang yang dibulatkan menjadi 400 orang pengguna smartphone Samsung yang berdomisili di kota Bandung. Pengumpulan data yang dilakukan dalam penelitian ini adalah dengan 
cara menyebarkan kuesioner atau angket. Kuesioner tersebut berisi sejumlah daftar pernyataan secara tertulis kepada responden.

\section{Teknik Analisis Data}

Teknik analisis data yang digunakan pada penelitian ini adalah metode regresi linier berganda. Menurut Sugiyono (2016:192) analisis regresi linier berganda merupakan regresi yang memiliki satu variabel dependen dan dua atau lebih variabel independen. Kemudian data diolah menggunakan SPSS versi 25.

\section{HASIL PENELITIAN DAN PEMBAHASAN}

\section{Hasil Penelitian}

\section{Analisis Deskriptif}

Brand awareness, brand association, perceived quality, dan brand loyalty merupakan faktor-faktor yang membentuk ekuitas merek. Berdasarkan persentase yang diperoleh dari masing-masing subvariabel, dapat diperoleh nilai ekuitas merek secara kesuluruhan, yaitu 82,6\% yang digambarkan dalam garis kontinum di bawah ini.

Gambar 3. Garis Kontinum Variabel Ekuitas Merek

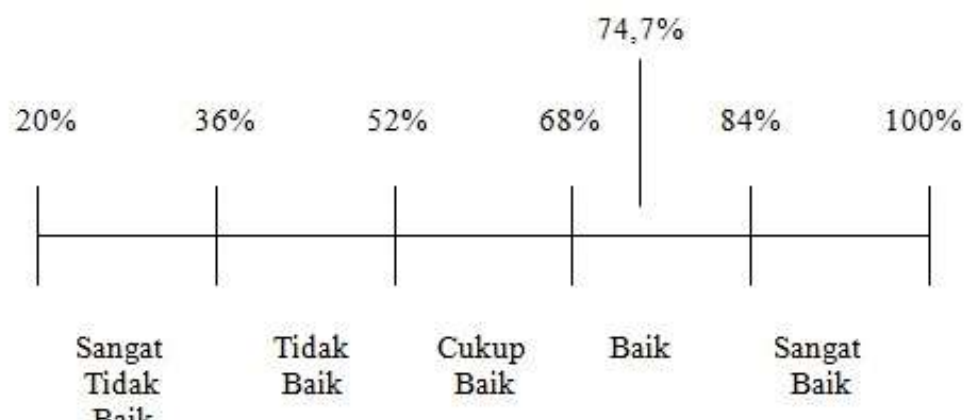

Sumber: Hasil Penelitian, diolah (2020)

Berdasarkan tanggapan responden mengenai variabel keputusan pembelian, diperoleh nilai rata-rata keseluruhan sebesar $86,8 \%$ dimana artinya variabel keputusan pembelian dinilai sangat baik yang diambarkan dalam garis kontinum di bawah ini.

Gambar 4. Garis Kontinum Variabel Keputusan Pembelian

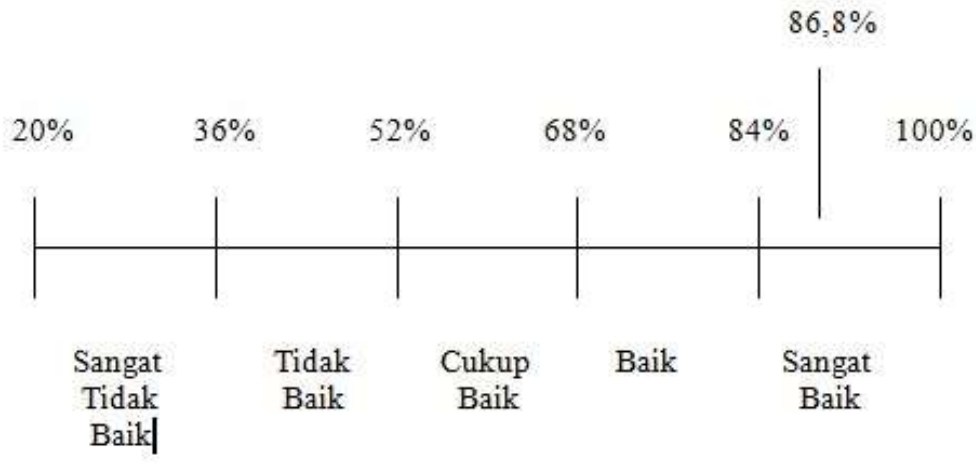

Sumber: Hasil Penelitian, diolah (2020) 


\section{Uji T}

Berdasarkan Uji $\mathrm{T}$ diperoleh nilai t hitung untuk variabel $\mathrm{X} 1$ adalah sebesar 3,610 dengan sig. 0,000 < 0,005. Hal tersebut menunjukkan bahwa brand awareness berpengaruh terhadap keputusan pembelian.

1. Nilai t hitung untuk variabel X2 adalah sebesar 2,026 dengan sig. 0,000 0,005. Hal tersebut menunjukkan bahwa brand association berpengaruh terhadap keputusan pembelian.

2. Nilai t hitung untuk variabel $\mathrm{X} 3$ adalah sebesar 5,068 dengan sig. 0,000 0,005. Hal tersebut menunjukkan bahwa perceived quality berpengaruh terhadap keputusan pembelian.

3. Nilai t hitung untuk variabel $\mathrm{X} 4$ adalah sebesar $-2,143$ dengan sig. $0,000<0,005$. Hal tersebut menunjukkan bahwa brand loyalty tidak berpengaruh terhadap keputusan pembelian.

\section{Koefisien Determinasi}

Berdasarkan koefisien determinasi, diperoleh nilai R-Square sebesar 0,172 itu artinya bahwa variabel X mampu menjelaskan $17.2 \%$ variabel $\mathrm{Y}$, sedangkan $82.8 \%$ dijelaskan oleh variabel lainnya selain variabel dalam penelitian ini.

\section{Uji F}

Berdasarkan uji simultan, diperoleh nilai $\mathrm{F}$ hitung sebesar 33,849 dimana nilai tersebut lebih besar dari nilai $\mathrm{F}$ tabel yaitu 3,94, dengan tingkat kesalahan $\alpha=5 \%$, atau dapat dikatakan F hitung $>\mathrm{F}$ tabel $(33,849>3,94)$.

Apabila nilai sig $<0.05$, maka variabel independen berpengaruh secara simultan terhadap variabel dependen. Berdasarkan hasil tersebut, terdapat hasil signifikansi sebesar $0.000<0.05$, maka variabel X1, X2, X3, dan X4 berpengaruh simultan terhadap variabel $\mathrm{Y}$ sehingga variabel independen berpengaruh secara simultan terhadap variabel dependen.

\section{Analisis Regresi Linear Berganda}

\section{Tabel 1. Analisis Regresi Linier Berganda}

\begin{tabular}{|c|c|c|c|c|c|c|c|c|c|c|c|c|c|}
\hline \multicolumn{14}{|c|}{ Coefficients $^{\mathrm{a}}$} \\
\hline & & \multicolumn{2}{|c|}{$\begin{array}{l}\text { Unstandardized } \\
\text { Coefficients }\end{array}$} & \multirow{2}{*}{$\begin{array}{c}\text { Standardized } \\
\text { Coefficients } \\
\text { Beta } \\
\end{array}$} & & \multirow[b]{2}{*}{ Sig. } & \multicolumn{2}{|c|}{$\begin{array}{c}95.0 \% \\
\text { Confidence } \\
\text { Interval for B }\end{array}$} & \multicolumn{3}{|c|}{ Correlations } & \multicolumn{2}{|c|}{$\begin{array}{l}\text { Collinearity } \\
\text { Statistics }\end{array}$} \\
\hline Mod & & B & $\begin{array}{l}\text { Std. } \\
\text { Error }\end{array}$ & & & & $\begin{array}{l}\text { Lower } \\
\text { Bound }\end{array}$ & $\begin{array}{l}\text { Upper } \\
\text { Bound }\end{array}$ & $\begin{array}{l}\text { Zero- } \\
\text { order }\end{array}$ & Partial & Part & Tolerance & VIF \\
\hline \multirow[t]{5}{*}{1} & (Constant) & 7.746 & .984 & & 7.875 & .000 & 5.812 & 9.680 & & & & & \\
\hline & TBAW & .268 & .074 & .189 & 3.610 & .000 & .122 & .414 & .341 & .179 & .162 & .741 & 1.349 \\
\hline & TBAS & .145 & .072 & .123 & 2.026 & .043 & .004 & .286 & .333 & .102 & .091 & .553 & 1.810 \\
\hline & TPQ & .317 & .062 & .322 & 5.068 & .000 & .194 & .440 & .394 & .248 & .228 & .502 & 1.993 \\
\hline & TPL & -.106 & .049 & -.129 & -2.143 & .033 & -.203 & -.009 & .203 & -.108 & -.096 & .563 & 1.777 \\
\hline
\end{tabular}

Sumber: Hasil Penelitian, diolah (2020) 
Persamaan regresi berganda dapat digunakan untuk mengetahui hubungan antar kedua variabel yang diperoleh sebagai berikut:

$$
Y=7,746+0,268 X_{1}+0,145 X_{2}+0,317 X_{3}+-0,106 X_{4}
$$

Berdasarkan persamaan tersebut, maka dapat diartikan sebagai berikut:

1. Brand awareness bernilai positif, jika brand awareness meningkat sebesar satu satuan maka nilai keputusan pembelian juga meningkat sebesar 0,268. Dan apabila brand awareness menurun sebesar satu satuan maka nilai keputusan pembelian juga menurun.

2. Brand association bernilai positif, jika brand association meningkat sebesar satu satuan maka nilai keputusan pembelian juga meningkat sebesar 0,145. Dan apabila brand association menurun sebesar satu satuan maka nilai keputusan pembelian juga menurun.

3. Perceived quality bernilai positif, jika perceived quality meningkat sebesar satu satuan maka nilai keputusan pembelian juga meningkat sebesar 0,317. Dan apabila perceived quality menurun sebesar satu satuan maka nilai keputusan pembelian juga akan menurun.

4. Brand loyalty bernilai negatif. Negatif menunjukkan pengaruh antara variabel dependen dan independen yang berlawanan, artinya jika brand loyalty meningkat sebesar satu satuan maka nilai keputusan pembelian juga menurun sebesar 0,106. Dan apabila brand loyalty menurun sebesar satu satuan maka nilai keputusan pembelian meningkat.

\section{KESIMPULAN DAN SARAN \\ Kesimpulan}

Berdasarkan data yang diperoleh dari hasil penelitian, maka dapat diambil kesimpulan sebagai berikut:

1. Berdasarkan analisis deskriptif dari tanggapan responden terhadap subvariabel ekuitas merek, memiliki nilai yang berbeda. Subvariabel Brand Awareness (X1) dengan nilai 88,5\% dengan kategori sangat baik, Brand Association (X2) dengan nilai 81,6\% dengan kategori baik Perceived Quality (X3) dengan nilai 85,95\% dengan kategori sangat baik, dan Brand Loyalty (X4) dengan nilai 74,7\% dengan dengan kategori baik dalam membentuk ekuitas merek. Dalam hal ini, subvariabel Brand Awareness merupakan subvariabel yang paling berpengaruh dalam mempengaruhi keputusan pembelian, artinya pengguna smartphone Samsung memiliki tingkat kesadaran yang tinggi terhadap produk tersebut dimana apabila ada produk Samsung, konsumen akan segera mengetahuinya.

2. Brand awareness memiliki pengaruh signifikan positif terhadap keputusan pembelian smartphone Samsung di kota Bandung. Hal ini ditunjukkan dengan nilai $\mathrm{t}$ hitung $(3,610)>\mathrm{t}$ tabel $(1,6449)$ dan nilai signifikansi $0,000<0,005$. Dengan nilai koefisien regresi sebesar 0,268. Artinya, jika brand awareness meningkat maka keputusan pembelian juga akan meningkat.

3. Brand association memiliki pengaruh signifikan positif terhadap keputusan pembelian smartphone Samsung di kota Bandung. Hal ini ditunjukkan dengan nilai $\mathrm{t}$ hitung $(2,026)>\mathrm{t}$ tabel $(1,6449)$ dan nilai signifikansi $0,000<0,005$. Dengan nilai 
koefisien regresi sebesar 0,145. Artinya, jika brand association meningkat maka keputusan pembelian juga akan meningkat.

4. Perceived quality memiliki pengaruh signifikan positif terhadap keputusan pembelian smartphone Samsung di kota Bandung. Hal ini ditunjukkan dengan nilai $\mathrm{t}$ hitung $(5,068)>\mathrm{t}$ tabel $(1,6449)$ dan nilai signifikansi $0,000<0,005$. Dengan nilai koefisien regresi sebesar 0,317. Artinya, jika perceived quality meningkat maka keputusan pembelian juga akan meningkat.

5. Brand loyalty tidak memiliki pengaruh signifikan positif terhadap keputusan pembelian smartphone Samsung di kota Bandung. Hal ini ditunjukkan dengan nilai $\mathrm{t}$ hitung $(-2,143)>\mathrm{t}$ tabel $(1,6449)$ dan nilai signifikansi $0,000<0,005$. Dengan nilai koefisien regresi sebesar -0,106. Artinya, apabila brand loyalty meningkat, maka tidak terjadi peningkatan dalam keputusan pembelian.

6. Brand equity memiliki pengaruh signifikan positif terhadap keputusan pembelian smartphone Samsung di kota Bandung. Hal ini ditunjukkan dengan nilai Fhitung > Ftabel (33.849 > 3.94). Dengan R Square sebesar 17,2\%. Artinya, brand equity memiliki pengaruh $17,2 \%$ terhadap keputusan pembelian smartphone Samsung di Kota Bandung.

\section{Saran}

Berdasarkan hasil kesimpulan yang telah diuraikan, penulis dapat memberikan beberapa saran sebagai berikut:

1. Saran bagi Perusahaan

Dilihat dari persentase pada analisis deskriptif, diperoleh persentase $74,4 \%$ pada subvariabel brand loyalty, yang merupakan persentase terendah di antara subvariabel lainnya pada pernyataan ekuitas merek. Maka dari itu, penulis menyarankan agar PT Samsung membuat program untuk mempertahankan kesetiaan pelanggan serta memperkuat customer relationship management agar pelanggan tidak beralih ke merek lain.

2. Saran bagi Peneliti Selanjutnya

Peneliti selanjutnya dapat menggunakan variabel yang sama tetapi akan lebih baik apabila mengembangkan penelitian ini dengan menambahkan variabel independen atau variabel intervening yang dapat mempengaruhi keputusan pembelian seperti variabel kualitas produk, inovasi, promosi penjualan, atau atribut produk.

Penelitian ini memiliki cakupan wilayah penelitian di kota Bandung sehingga tidak dapat mewakili semua wilayah di Indonesia, oleh karena itu penelitian selanjutnya perlu dilakukan dengan cakupan penelitian yang lebih luas untuk seluruh Indonesia, atau di wilayah yang belum dilakukan penelitian sebelumnya.

Penelitian selanjutnya dapat menjadikan penelitian ini sebagai acuan apabila penelitian ini memiliki kesamaan variabel dengan penelitian selanjutnya dengan objek yang berbeda tetapi masih dalam bidang yang sama, yakni dalam bidang elektronik.

Apabila penelitian selanjutnya menambahkan variabel independen yang lain, maka dapat menggunakan metode penelitian yang lain, misalnya metode SEM. 


\section{DAFTAR PUSTAKA}

Databoks. Samsung Bertahan Jadi Pemimpin Pasar Smartphone Dunia. Retrieved from https://databoks.katadata.co.id/datapublish/2019/12/04/samsungpertahankan-posisi-pemimpin-pasar-smartphone-dunia [12 April 2020]

Sudarsono, Deby Susanti dan Dyah Kurniati. 2013. Elemen Ekuitas Merek Dalam Keputusan Pembelian Laptop. Jurnal Riset Manajemen dan Akuntansi. Vol. 1. No. 1. Februari 2013. Hal. 18 - 27. Universitas Katolik Widya Mandala. Madiun.

Buchori, H., A, dan Saladin, D. 2010. Manajemen Pemasaran (Ringkasan Praktis, Teori, Aplikasi \& Tanya Jawab Edisi Pertama). Indonesia: CV Linda Karya

Firdananda, W., Djaja, S., dan Sudikin. 2017. Pengaruh Ekuitas Merek Terhadap Proses Pengambilan Keputusan Pembelian Motor Honda Beat di Dealer Garuda Motor I Kecamatan Gambiran Kabupaten Banyuwangi. Vol 11 no 1. Indonesia: Jurnal Ilmiah Pendidikan.

Kotler, P., dan Keller, K. L. 2007. Manajemen Pemasaran (edisi 12 Bahasa Indonesia). Bandung, Indonesia: PT Machanan Jaya Cemerlang.

Kusumawardani, A., dan Munandar, J., M. 2018. Pengaruh Sepuluh Ekuitas Merek Terhadap Minat Beli dan Keputusan Pembelian Sepatu Bata Berdasarkan Sikap Konsumen. Vol 8 no 2. Indonesia: Jurnal Ilmiah Manajemen.

Wirdamulia, A. 2019. Strategi Pengelolaan Merek (cetakan 1). Bogor, Indonesia: Percetakan IPB. 